\title{
Strategic Accounting in the Profitability of Construction Engineering Projects Management Companies in Iraq
}

\author{
${ }^{1}$ Mohammed Noori Hussein Al-Hashimi and ${ }^{2}$ Hisham Noori Hussain Al-hashimy \\ ${ }^{1}$ Department of Civil Engineering, Iraq University College, Basra, Iraq \\ ${ }^{2}$ Department of Accounting, College of Management and Economics, \\ University of Basra, Basra, Iraq
}

\begin{abstract}
This research examines how to create a special record for pricing quantities in the engineering projects carried out by the construction companies in Iraq as the purpose of this research is the application of strategic management accounting in engineering projects in the pricing of construction companies accounting manner that ensures the highest rate of profitability and avoid loss. It has been linked to the engineering contract construction licenses for the purposes of pricing and then linked and pricing through strategic accounting management through balancing the balanced performance of each paragraph in the contract item. How a balanced scorecard can price the rotation of engineering projects submitted for tenders. It will require pricing command to apply the method of the balanced scorecard in pricing. Engineers must also understand and research on this method, linking engineering and administrative work. This system stimulates the balanced scorecard method used for strategic management accounting in tenders pricing. How can the balanced scorecard that the rotation of the four pricing according to its terms and to make the estimated profit expected for this tender and for each element and how to make balanced scorecard card results have fixed and approved mechanism in engineering prices.
\end{abstract}

Key words: Strategic accounting, profitability, construction engineering projects management, balanced scorecard, management, construction companies

\section{INTRODUCTION}

The Balanced scoredcard (Bsc) approach, first introduced by Kaplan and Norton (2001) has been widely adopted by many companies and is viewed by researchers as a strategic management tool in developing a performance management system. Following on the initial approach which attempted to identify specific measures from a broader perspective (Kaplan and Norton, 2004) further suggested creating a strategy map which emphasized the linkages among these four perspectives. The BSC approach has evolved from a measurement system to a communication system that provides a one-page graphical representation of what an organization must do well in each of the four perspectives to successfully execute a strategy (Arendrup et al., 2006).

In this study, we discuss the balanced scoredcard and SWOT analysis of the Banaat Iraq Contracting Company in Iraq. Banaat Iraq is a Iraqi-based investment holding company engaged in civil engineering construction and operates in three business segments: engineering and construction, property development and club operations and water and expressway concessions.

The company delivers innovative world-class infrastructure and homes through its core businesses in infrastructure development and construction, operation and maintenance of public infrastructure concessions and large-scale urban property development. The vision statement of the company stated" We aim to lead the region in innovative breakthrough solutions for large scale public infrastructure and property development". while the mission statement included "We reliably deliver innovative world-class infrastructure and premier lifestyle properties for our customers through our core businesses in infrastructure development and construction, operation of infrastructure facilities and property development". The steps for each engineering project should be taken into account. Each stage of the project requires the efforts of specialized cadres of engineers, technicians and workers. All of these must be included in the accounting system or cost when preparing a project accounting program for the project. Figure 1 show the steps for each engineering projects should be considered.

Corresponding Author: Mohammed Noori Hussein Al-Hashimi, Department of Civil Engineering, Iraq University College, Basra, Iraq 

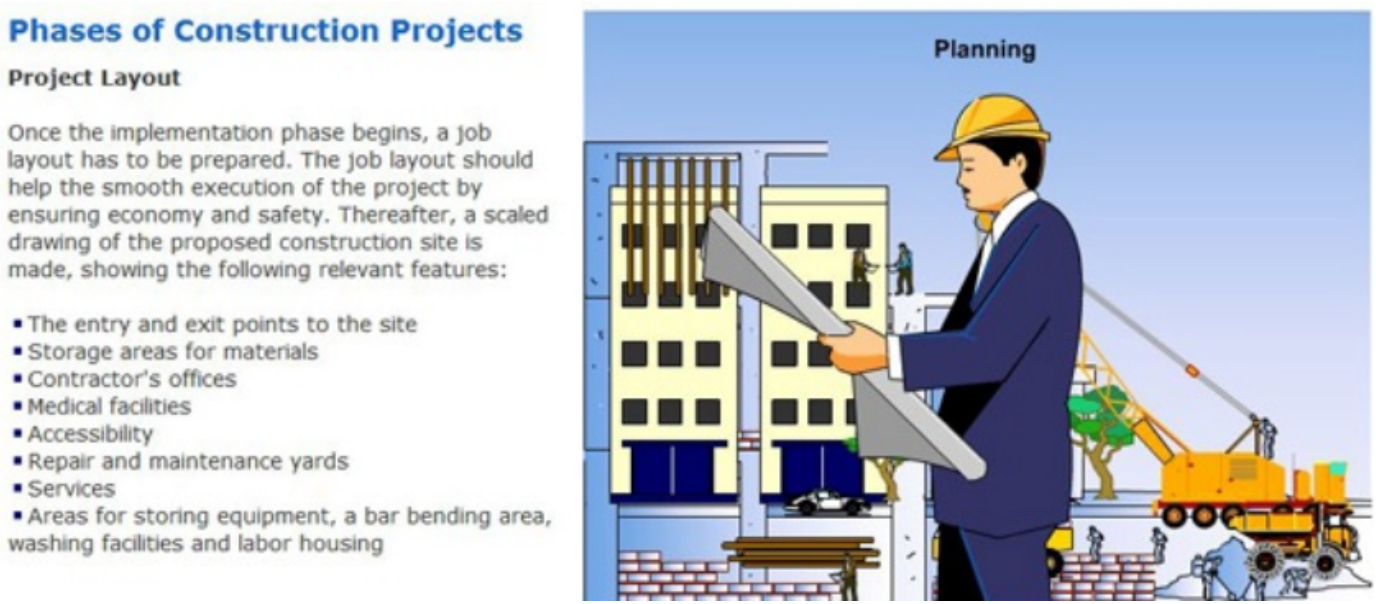

Fig. 1: Phases of construction projects

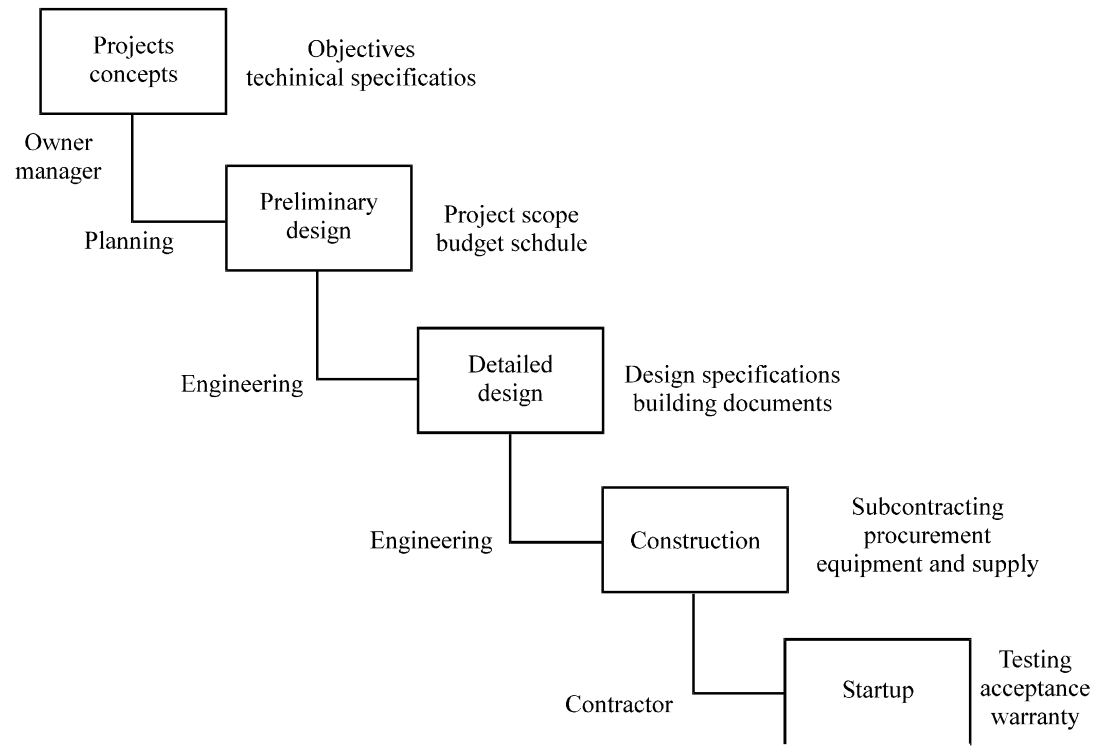

Fig. 2: Steps of engineering projects

\section{MATERIALS AND METHODS}

We show in the Fig. 2 plan the methods of analysis of the balanced balance scorecard which are the strengths, weaknesses, threats and opportunities which we will link to the strategy of ratification for the Iraqi contracting company in terms of financial and customer wages and the internal financial and administrative affairs of the company and how to develop (Asosheh et al., 2010).

Construction engineering companies, like other companies cannot professional engineering staff in which the project management properly and identify the strengths, weaknesses, opportunities and mistakes but drawing on the experiences of accounting and administrative or are developing themselves administratively and accounting for project management in the best way to achieve greater profitability desired (Eshtehardian et al., 2013) (Fig. 3).

Analysis/SWOT analysis strengths: The main strength is that the company has expressed its willingness and willingness to act on behalf of the company in dealing with other governments. Another strength is the financial capabilities of the company. The company still has revenue when major competitors or other regional airlines have recorded losses (Houben et al., 1999). In addition, the company has a leadership that has experience and knowledge in managing the company and has managed to transform the company into one of the most successful 


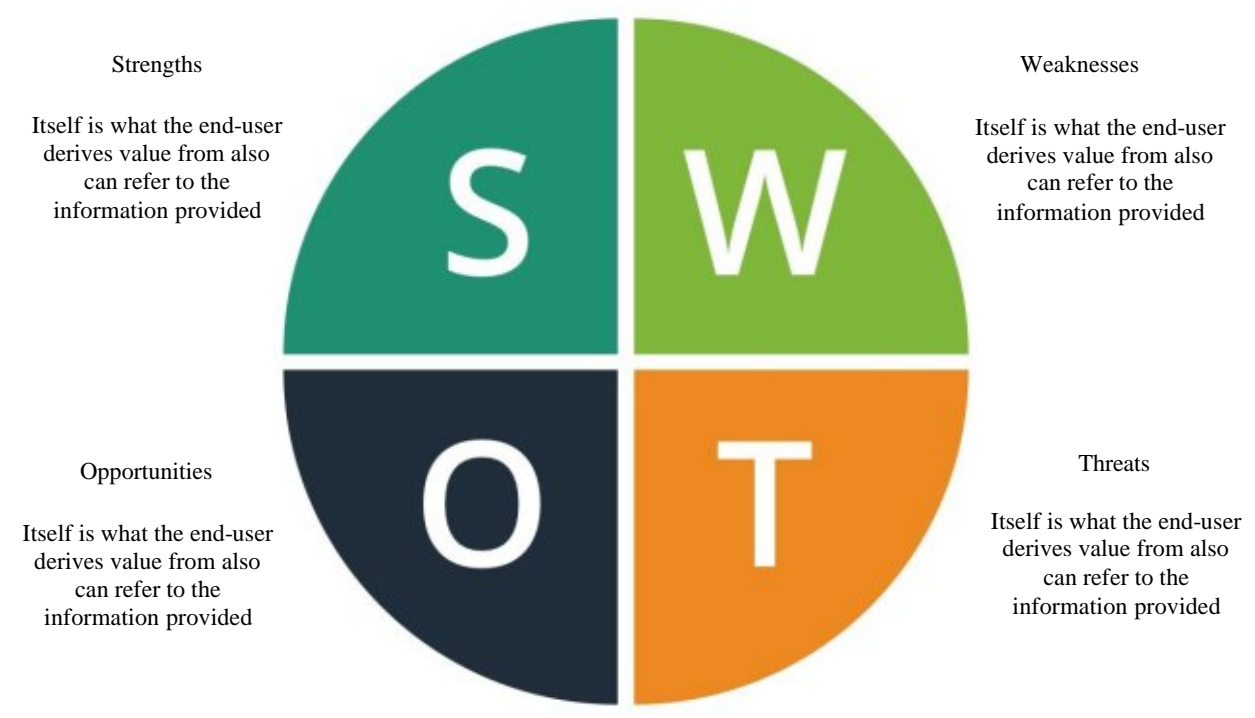

Fig. 3: SWOT analysis

companies in the world. In addition to management, staff are well-educated, well-trained and ready to work in the company which can improve customer service. The company has strong marketing capabilities where marketing is able to deliver the company's message and reach customers around the world. Finally, the company has a good reputation in the aviation industry and has been described as a pioneer in innovation where the latest airlines are employed and employed in the company (Huerta et al., 2003). The age of the fleet is another strength of the company with an average age of 6 years and the company can earn its reputation and reduce maintenance costs (Hay and Castilla, 2006).

Weaknesses: There are a few weaknesses in the company. Weaknesses are mainly related to the strategic decision-making process where the company does not have the appropriate expertise at the beginning of its establishment and the other bonuses have been signed on the basis of reference to many of the confusion in the accounts (Miller 2007). Other weaknesses are strategic alliances and acquisitions (Hill and Westbrook 1997).

Opportunities: The company can take advantage of many opportunities. Difficult situations competitors could enable the company to expand its share in the tenders. Most competitors in Iraq do not have the experience and high grades. Other opportunities include advances in information technology and the Internet. The company can spread this opportunity to strengthen its position and create competitive advantages (Hay and Castilla, 2006).

Threats: The company faces many threats to refer tenders and Iraq has recently faced a terrorist attack targeting the north of Iraq (Kurttila et al. 2000), resulting in most of the state funds spent on this attack in addition to that the company faces some corrupt almqulin who pay money for the purpose of taking tenders legal (Dyson, 2004). A summary of the SWOT analysis is presented in Table:

\section{Strengths:}

- Large capital

- Final accounts are accurate

- Youth managers

- Well-trained staff 5-strong marketing

- Reputation

Weaknesses:

- Delayed salaries of employees

- Taking projects greater than the company's strategic capacity

\section{Opportunity:}

- Taking projects simply because of the partner's experience

- Advanced pricing methods

\section{Threats:}

- Adopting illegal methods from some companies to take projects

- Low state revenues

- Terrorist attacks

\section{RESULTS AND DISCUSSION}

For the balanced scorecard, Table 1 shows the perspectives and the recommended strategies for the 
Table 1: The perspectives and the recommended strategies for the companies

\begin{tabular}{|c|c|c|c|c|}
\hline \multirow[b]{2}{*}{ Variables } & \multicolumn{4}{|l|}{ Strategy } \\
\hline & Objectives & Measures & Targets & Initiatives \\
\hline \multirow[t]{2}{*}{ Financial } & Increase revenue & ROI & $7 \%$ & Try taking different projects \\
\hline & Increase liquidity & Money & $13 \%$ & Increase revenues by opening capital support projects \\
\hline \multirow[t]{2}{*}{ Customers } & Improve customer service & Service index & $6-8$ & $\begin{array}{l}\text { Try to identify problems with the processors and } \\
\text { resolved through dialogue }\end{array}$ \\
\hline & Improve customer satisfaction & Customer satisfaction index & $7-9$ & $\begin{array}{l}\text { Find out what attracts people to give their projects to } \\
\text { the company and what are their demands }\end{array}$ \\
\hline $\begin{array}{l}\text { Internal } \\
\text { process }\end{array}$ & $\begin{array}{l}\text { products and services conform } \\
\text { to customer requirements }\end{array}$ & Satisfaction index & $7-9$ & $\begin{array}{l}\text { Conduct a survey to find customer satisfaction and business } \\
\text { the fulfillment of the task of the company }\end{array}$ \\
\hline \multirow[t]{2}{*}{$\begin{array}{l}\text { Learning and } \\
\text { growth }\end{array}$} & $\begin{array}{l}\text { Improve employ ee training } \\
\text { and development }\end{array}$ & Employee satisfaction index & $6-10$ & $\begin{array}{l}\text { Conduct periodically training to increase the } \\
\text { employ ee skills and competence }\end{array}$ \\
\hline & $\begin{array}{l}\text { Transferring the company } \\
\text { to knowledge company }\end{array}$ & Knowledge index & $3-10$ & $\begin{array}{l}\text { Creating culture of knowledge sharing and applying } \\
\text { best practice and lesson learned }\end{array}$ \\
\hline
\end{tabular}

companies. We note well through the results that engineers in construction companies need accounting and managerial skills for the purpose of pricing projects in a proper manner, we note also that the profitability of contracting companies and measuring their losses is through the management of a sound accounting strategy. Note that the balanced scorecard and its use in the pricing of projects have an effective and sensitive role. This method should be adopted and developed by making basic and consistent controls for the process.

\section{CONCLUSION}

How can the balanced scorecard that the rotation of the four pricing according to its terms and to make the estimated profit expected for this tender and for each element and how to make balanced scorecard card results have fixed and approved mechanism in engineering prices.

\section{REFERENCES}

Arendrup, C.M., R.B. O'Driscoll, E. Petersen and D.W. Denning, 2006. Acute pulmonary Aspergillosis in immunocompetent subjects after exposure to bark chippings. Scand. J. Infect. Dis., 38: 945949.

Asosheh, A., S. Nalchigar and M. Jamporazmey, 2010. Information technology project evaluation: An integrated data envelopment analysis and balanced scorecard approach. Expert Syst. Appl., 37: 59315938.

Dyson, R.G., 2004. Strategic development and SWOT analysis at the University of Warwick. Eur. J. Operat. Res., 152: 631-640.
Eshtehardian, E., P. Ghodousi and A. Bejanpour, 2013. Using ANP and AHP for the supplier selection in the construction and civil engineering companies: Case study of Iranian company. KSCE. J. Civ. Eng., 17: 262-270.

Hay, G.J. and G. Castilla, 2006. Object-based image analysis: Strengths, Weaknesses, Opportunities and Threats (SWOT). Proceedings of the 1st International Conference on Archives of the Photogrammetry, Remote Sensing and Spatial Information Sciences (OBIA 2006), July 4-5, 2006, University of Salzburg, Salzburg, Austria, pp: 1-3.

Hill, T. and R. Westbrook, 1997. SWOT analysis: It's time for a product recall. Long Range Planning, 30: 46-52.

Houben, G., K. Lenie and K. Vanhoof, 1999. A knowledgebased SWOT-analysis system as an instrument for strategic planning in small and medium sized enterprises. Decis. Support Syst., 26: 125-135.

Huerta, M., R.D. Balicer and A. Leventhal, 2003. SWOT analysis: Strengths, weaknesses, opportunities and threats of the Israeli Smallpox Revaccination program. Isr. Med. Assoc. J., 5: 42-46.

Kaplan, R.S. and D.P. Norton, 2001. Transforming the balanced scorecard from performance measurement to strategic management: Part I. Accounting Horiz., 15: $87-104$.

Kaplan, R.S. and D.P. Norton, 2004. Strategy Maps: Converting Intangible Assets into Tangible Outcomes. Harvard Business School Press, Boston.

Kurttila, M., M. Pesonen, J. Kangas and M. Kajanus, 2000. Utilizing the Analytic Hierarchy Process (AHP) in SWOT analysis: A hybrid method and its application to a forest-certification case. Forest Policy Econ., 1: 41-52.

Miller, M.G., 2007. Environmental metabolomics: A SWOT analysis (Strengths, Weaknesses, Opportunities and Threats). J. Proteome Res., 6: 540-545. 